\title{
FLOW OVER BROAD-CRESTED WEIR WITH INFLOW BY APPROACH SHAFT - NUMERICAL MODEL
}

\author{
Jakub Major ${ }^{1}$, Martin Orfánus ${ }^{2}$ and Zbyněk Zachoval ${ }^{3}$
}
1. AQUATIS a.s., Botanická 834/56, Brno, Czech Republic; jakub.major@aquatis.cz
2. Slovak University of Technology in Bratislava, Faculty of Civil Engineering, Department of Hydraulic Engineering, Bratislava, Slovakia; martin.orfanus@stuba.sk

3. Brno University of Technology, Faculty of Civil Engineering, Institute of Water structures, Brno, Czech Republic; zachoval.z@fce.vutbr.cz

\section{ABSTRACT}

In the case of flow over rectangular broad-crested weir, where the inflow is realized by approach shaft, occurs influence of water surface level by approach flow velocity. The paper describes numerical model of flow including weir, approach and outlet shaft. Simulations of flow were created by 2D and 3D model with using three methods of turbulent modelling. In this paper a water surface level for each model setup is evaluated and then it is compared with measured values.

\section{KEYWORDS}

Approach shaft, Broad-crested weir, Free surface level, Numerical model

\section{INTRODUCTION}

In practice there are also used broad-crested weirs with approach shaft to determine the discharge, eventual to regulate the water surface level (laboratories, pond inlet structures, wastewater treatment plants, weirs of retention basins in sewer systems, etc.) (Chyba! Nenalezen zdroj odkazů.).

In the professional literature, the flow over the mentioned weir with the approach shaft is described in the publications Chyba! Nenalezen zdroj odkazů., Chyba! Nenalezen zdroj odkazů. and Chyba! Nenalezen zdroj odkazů., which are based on extensive experimental research. From the experimental research is known the water surface profile in the longitudinal plane of symmetry of the approach shaft and weir, as well as the pressure height on the approach shaft walls for the full range of geometric dimension ratios used in practice [2], [4]. The water surface level in the approach shaft and the velocity field in the wake area at the weir crest are known only for specific geometric and flow conditions [3], [4].

As the authors know, at present only models of overflow over broad-crested weir with vertical inflow are performed [5], [6], [7], [8] and [9], but none of the authors dealt with numerical modelling of overflow over broad-crested weir with approach shaft.

The aim of the research was creating a suitable numerical model for the most reliable description of the flow over rectangular broad-crested weir with inflow by approach shaft. Model was validated on the basis of measured water surface level profile. The results of the simulations could be used to supplement the measured data from experimental research. 


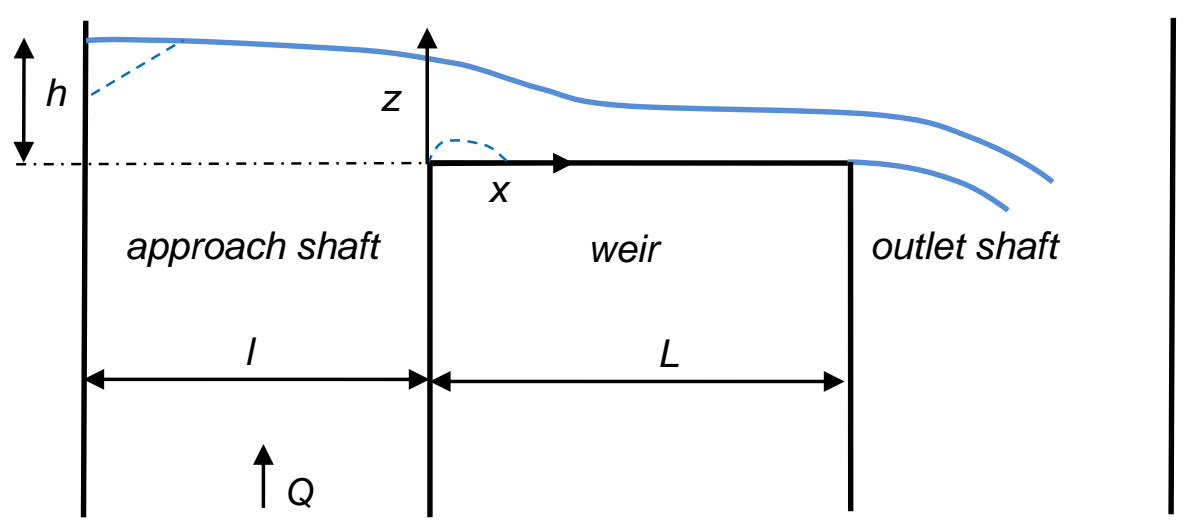

Fig. 1 - Scheme of flow over broad-crested weirs with approach shaft

\section{WEIR GEOMETRY}

The weir geometry, approach shaft and outlet shaft were created in the software FLOW-3D version 11.0.4 [10], in which calculations were also performed. Two concepts of model construction were used to evaluate their advantages and disadvantages. The 2D model used the concept of fixed blocks, which defined the space for flow by two blocks of the network (Figure 2, left). The width of the fixed blocks was $2 \mathrm{~m}$, the width of the blocks of the computer network was the same as the width of the weir. There were three solid blocks. The first block (red in Figure 2) formed the opposite wall of the inlet shaft with respect to the weir. The second block (blue in Figure 2) formed a broad-crested weir, an adjacent wall of the inlet shaft and an adjacent wall of the outlet shaft. The third block (yellow in Figure 2) formed the opposite wall of the outlet shaft. Their mutual location was chosen so that the nodes of the network were in one case at the boundaries of the computational area and in the other case were not. The 3D model used the concept of five blocks of a network to define the space through which water can flow (Figure 2).

The weir had a length in the direction of flow $L=0.650 \mathrm{~m}$. The side walls of the weir and the shaft were elevated $0.500 \mathrm{~m}$ above the crest of the weir. The weir, the approach shaft and the outlet shaft were same width $b=0.500 \mathrm{~m}$. The length of the approach shaft was $I=0.300 \mathrm{~m}$ and its height was $4 \mathrm{~m}$. In the case of a 3D model due to the reduction of the number of cells, the height was only $2 \mathrm{~m}$. The length and height of the outlet shaft were the same as for the approach shaft. The overflow was free with a fully aerated nappe in the outlet shaft.

\section{SIMULATIONS}

To describe the water surface level a simulation using a 2D and $3 \mathrm{D}$ model for the head $h=0.253 \mathrm{~m}$ (measured $0.05 \mathrm{~m}$ from the shaft wall) at discharge $0.090 \mathrm{~m}^{3} / \mathrm{s}$ ) was performed, therefore for a $/ / h$ ratio of approximately 1.2. Simulations were performed with RANS (Reynoldsaveraged Navier-Stokes) turbulence models $k-\omega, k-\varepsilon$ and $L E S$ (Large eddy simulation). Information on individual turbulence models can be found in publications [10], [11] and [12], due to their scope and general knowledge they are not given here. Steady flow was solved with a free water surface, one incompressible fluid (water) with density $1000 \mathrm{~kg} / \mathrm{m}^{3}$ and kinematic viscosity $0,001 \mathrm{~m}^{2} / \mathrm{s}$. It was considered with a surface tension $0,073 \mathrm{~N} / \mathrm{m}$. The threshold deviation in the calculation was set to $2 \%$ [2]. 
The coordinate system has been chosen so that $x$ coordinate defined the length of the shaft and crest of weir in the flow direction, the $y$ coordinate defined the width of the shaft and the weir and the $z$ direction the height of the shaft.

Boundary conditions of several types are described in Figure 2. The boundary condition at the inflow (bottom of the approach shaft) for 2D simulation was entered as the inflow velocity (V) corresponding to the specific discharge of the given state. The boundary condition at the inflow for the 3D simulation was entered as a pressure $(P)$. The advantage of entering the velocity is the direct calculation, the disadvantage is relatively unstable solution. The advantage of entering the pressure is a stable solution, the disadvantage is the indirect (iterative) calculation. The wall boundary condition (W) with a hydraulically smooth surface was specified on all solid walls. The symmetric boundary condition (S) was specified at the junction of the network blocks. The free outflow $(\mathrm{O})$ was entered at the outflow section of the outlet shaft and at the air boundaries (Figure 2). The initial condition was the hydrostatic pressure distribution along the height of the calculation space from the measured water level. The initial water level was entered as a horizontal level over the weir crest.

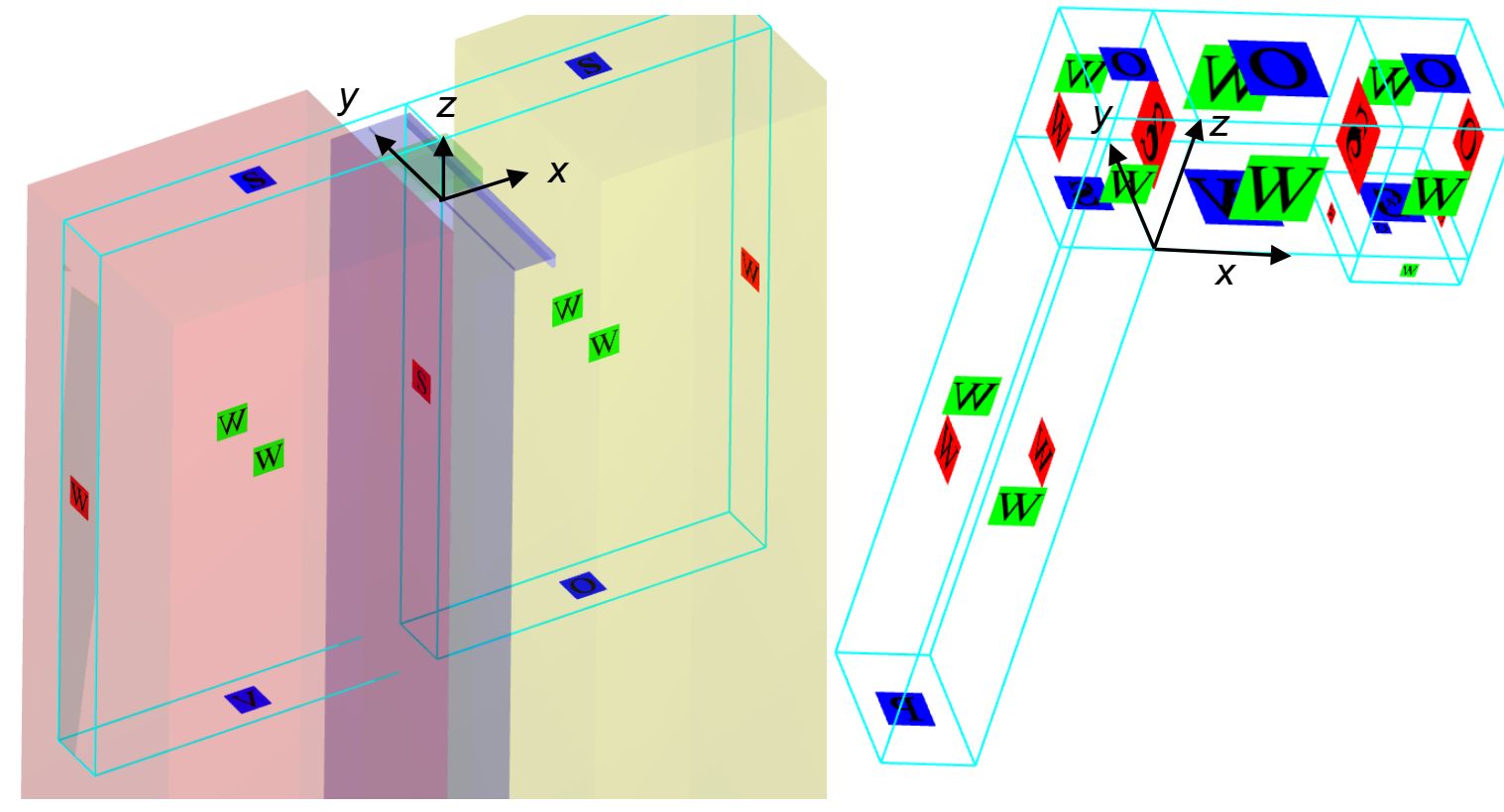

Fig. 2 - Scheme of calculation area and entering boundary conditions for 2D model (left) and for 3D model (right)

During the calculations, three analyses were performed to determine the minimum requirements for the models so that the results were conclusively and repeatable.

The first analysis concerned the influence of the position of the structured rectangular mesh against the solid walls, when it was shown that the mutual position influences the results. The effect on the water surface level was up to $0.004 \mathrm{~m}$, the change was mainly reflected in the velocity field near the walls. For reasons of repeatability, a position was chosen where the nodes of the network corresponded to the surface of the solid wall.

The second analysis concerned the effect of cell size on the results. A 2D model with a $k-\omega$ turbulence model was used for the analysis. The length of the cell edges in the calculation area was gradually reduced until the water level did not change by more than $0.001 \mathrm{~m}$. This state occurred at a cell size length (in the $x$ and $z$ direction) of $0.005 \mathrm{~m}$ in the whole calculation area. In the $y$ direction, the size of the cells in the 3D model was set to $0.010 \mathrm{~m}$ over the whole width of the area. Guidelines for good mesh quality specified by FLOW-3D was satisfied. The maximum aspect 
ratio within a single cell was less than 3 , the maximum adjacent cell size ratio was less than 1.25 , the maximum inter-block cell size ratio was less than 2 , and mesh planes coincide in the boundaries.

The third analysis concerned the minimum required shaft height. A 2D model was used for the analysis, where the development of the velocity field and the influence of the shaft length on the water surface level were monitored. It turned out that the height of the approach shaft $2 \mathrm{~m}$ below the weir crest was sufficient due to achieve a constant velocity distribution along the shaft height. It was also determined that the height of the outlet shaft $0.100 \mathrm{~m}$ below the weir crest will suffice, when the position of the network boundary does not affect the water surface level above the weir.

The total number of cells in the 2D model was 183911 , of which 46366 were active. In the 3D model, the total number of cells was 4114141 , all cells were active. The stabilization time was determined based on the change in water surface level over time. The criterion was a change of water surface level smaller than $0.001 \mathrm{~m}$ during $10 \mathrm{~s}$. Flow was stabilized in $20 \mathrm{~s}$ at the latest. A standard desktop computer was used for the calculations (Intel i7, 4 cores, 4,6 GHz, 8 GB RAM). The calculation time lasted in the case of a $2 \mathrm{D}$ model in the range of 3 to 4 hours, in the case of a 3D model 1 to 2 days, depending on the overflow height.

\section{EVALUATION AND COMPARISON}

Water levels in the longitudinal plane of symmetry for 2D and 3D models and water levels in the entire approach shaft were evaluated using RANS turbulence models $k-\omega, k-\varepsilon$ and the LES model. The evaluation was performed in MS Excel. The values were then compared with the measured values [3]. In summary, the experimental model has the length of the weir $0.650 \mathrm{~m}$, widths of the weir as well as the shaft $b=0.500 \mathrm{~m}$, and height of the shaft $4.02 \mathrm{~m}$. Discharge was $0.090 \mathrm{~m}^{3} / \mathrm{s}$. The broad-crested weir and the right downstream wall of the weir were made from polymethyl methacrylate with a thickness of $0.010 \mathrm{~m}$. The left downstream wall was made of waterproof plywood with a thickness of $0.021 \mathrm{~m}$. Water surface was measured by the point gauge and discharge by the electromagnetic flowmeter. Free overflow was achieved. The space underneath the nappe was fully aerated.

Figure 3 shows measured and calculated (2D and 3D) water surface longitudinal profile (turbulence model $k-\omega$ ). Figure 4 shows measured water surface longitudinal profile and calculated (3D model) by RANS turbulence models $k-\omega, k-\varepsilon$ and the $L E S$ model.

From the comparison of calculated and measured water surface profiles shown in Figure 3 and Figure 4 is visible the quantitative difference. All numerical models underestimate the water surface level. The difference between the calculated and measured values is up to $-0,016 \mathrm{~m}$. From Figure 3 , the water surface profile in the $3 \mathrm{D}$ model is qualitatively similar to the measured. From the above, the flow simulation using a 3D model better captures measured water surface than using a 2D model, which is due to the inclusion of friction against the side walls in 3D model. From Figure 4 it is visible that the $k-\omega$ model describes water surface profile the most accurately. 
CIVIL

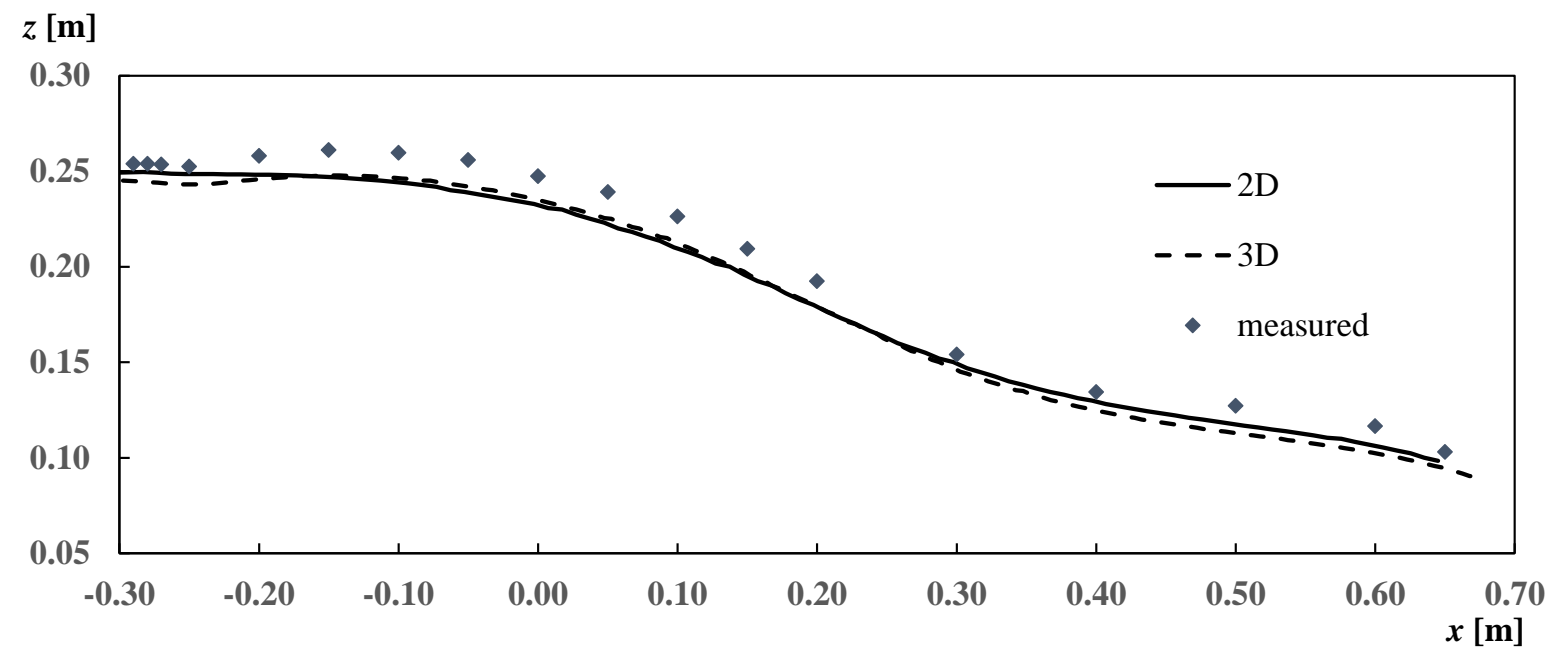

Fig. 3 - Longitudinal water surface profile, turbulence model $k-\omega$, influence of model dimension

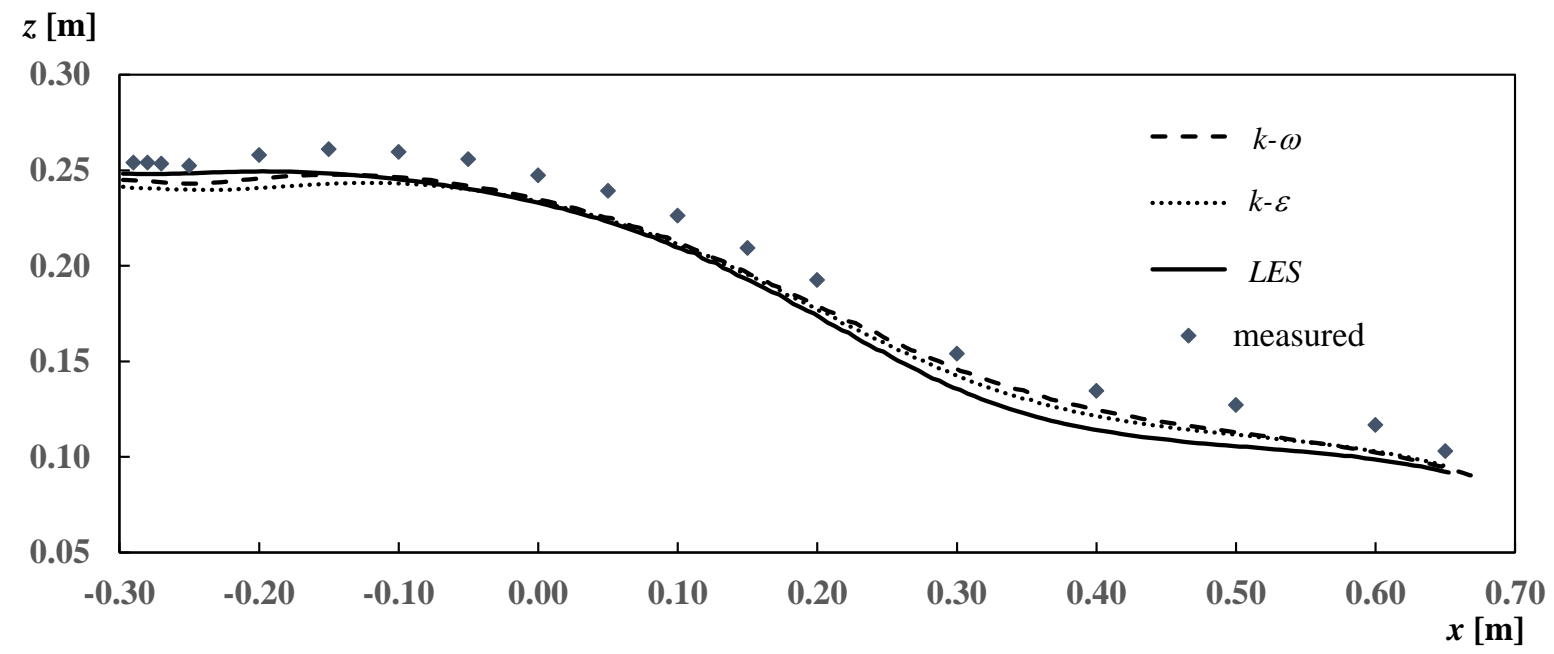

Fig. 4 - Longitudinal water surface profile, 3D model, influence of turbulence model

Figure 5 shows the relative error of the calculated water surface level profiles for the individual turbulence models, where $h_{M}$ is measured water surface level and $h_{V}$ is calculated for the individual models.

From Figure 5 it is visible that for $x<0.15 \mathrm{~m}$ the turbulence models show a relative error up to $10 \%$, in the range $0.15 \leq x \leq 0.65$ up to $18 \%$. 


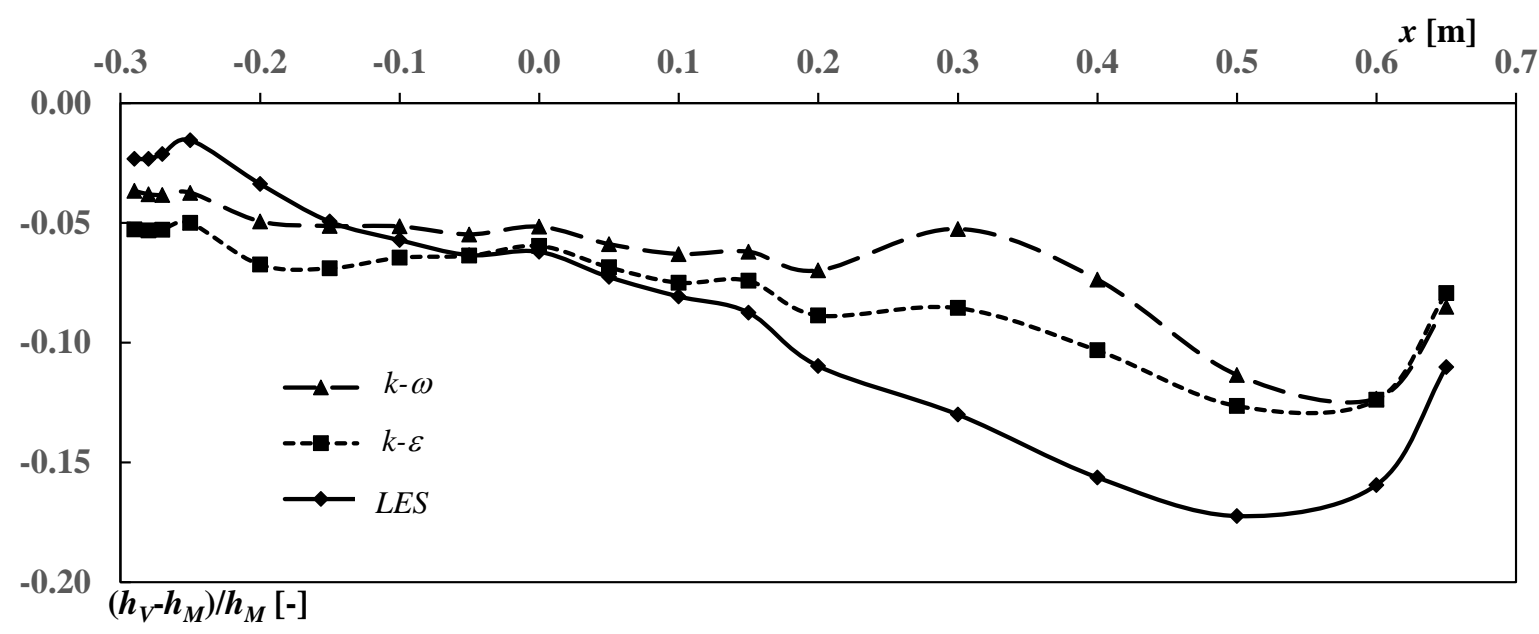

Fig. 5 - Relative error of the calculated water surface profiles for individual models

The water surface levels in the whole approach shaft calculated by $2 \mathrm{D}$ and $3 \mathrm{D}$ model were evaluated in the program SMS 12.3. Figure 6 shows the isolines of the water surface level (relative to the weir crest level) calculated by $2 \mathrm{D}$ and $3 \mathrm{D}$ model using the $k$ - $\omega$ model of turbulence and isolines from the measured values (linear interpolation on a triangular mesh) Chyba! Nenalezen zdroj odkazů..
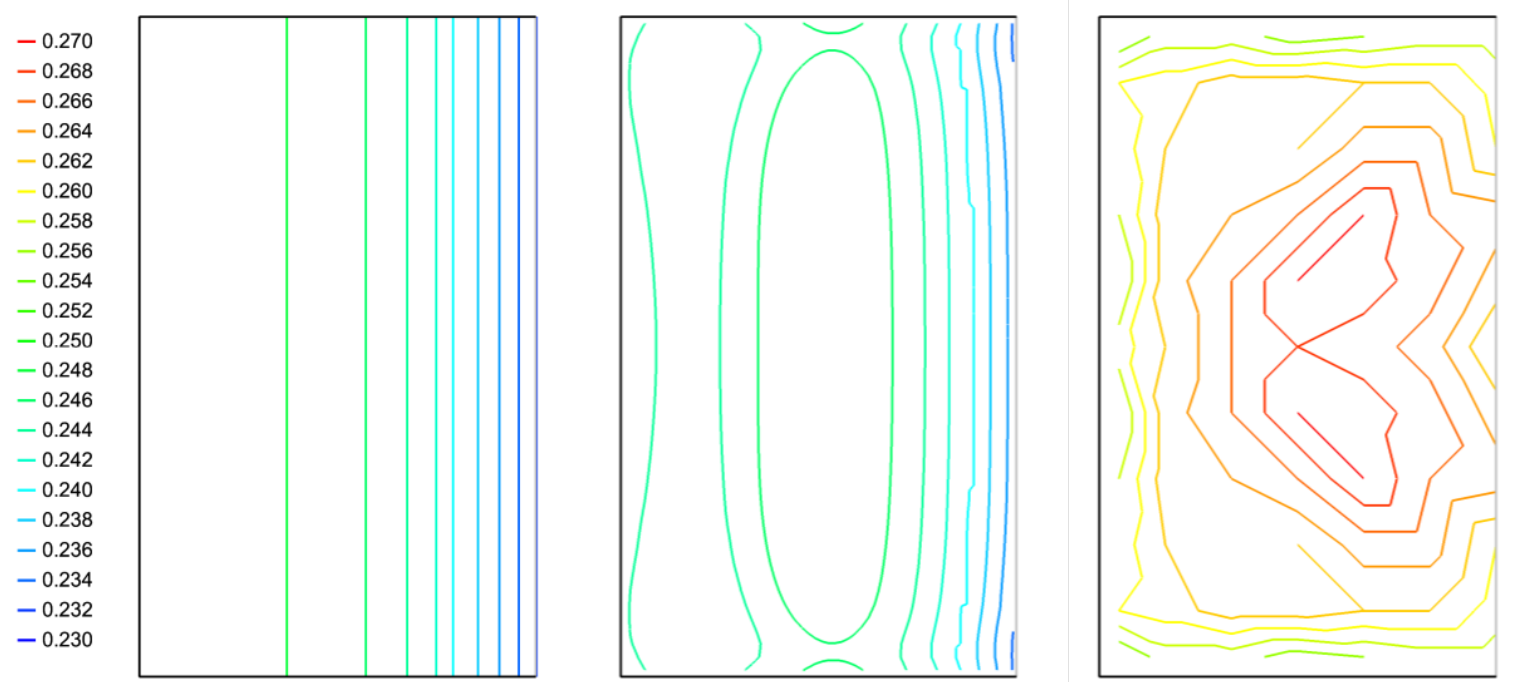

Fig. 6 - Water surface level above weir crest [m] in the approach shaft, left - 2D model, middle $3 D$ model and right - measured, the right boundary of the area defines the upstream edge of the weir crest 


-0
--1
--2
-3
--4
--5
--6
--7
--8
--9
--10
--11
--12
--13
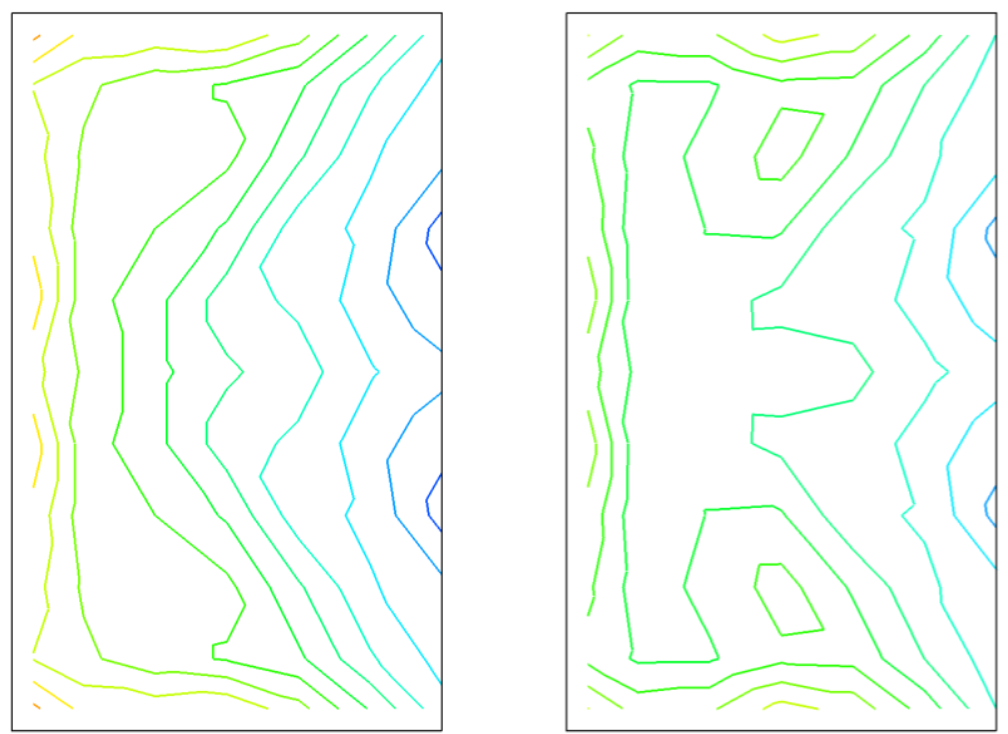

Fig. 7-Deviation [\%] of computed values of water surface level above the weir crest in the approach shaft from measured values, left - 2D model, right - 3D model, the right boundary of the area defines the upstream edge of the weir crest

In Figure 6 there are visible differences in the water surface levels of the calculated 2D and $3 \mathrm{D}$ models compared to the measured. In the Figure 7 there is visible the deviation of the computed values of the water surface level above the weir crest in the approach shaft from measured values.

In the case of 2D model, the water surface level is constant across the entire width of the inflow shaft. The water level does not correspond quantitatively and qualitatively to the measured water level. The given shape is similar to the conditions at lower overflow heights or large lengths of the approach shaft [2]. The difference between the calculated and measured water surface level is up to $-0.033 \mathrm{~m}$ (deviation $-12 \%$ ). The largest deviations are at the upstream edge of the weir crest.

In the case of $3 \mathrm{D}$ model, the results are quantitatively different, but qualitatively more similar to those measured. Near the approach shaft walls, the water surface level is lower, in the middle of the shaft it is higher. The difference is up to $0.006 \mathrm{~m}$. The difference between the calculated and measured water surface level is up to $-0.030 \mathrm{~m}$ (deviation $-11 \%$ ). The largest deviations are at the upstream edge of the weir crest.

\section{CONCLUSION}

The numerical models in the case of flow over a broad-crested weir with approach shaft made it possible to determine the flow characteristics relatively quickly. The use of solid blocks in modelling allows for quick model creation, but at the cost of large number of inactive cells and frequent non-matching of the surface with the cell edges. Modelling without their use seems to be more suitable in terms of accuracy and complexity of calculation. It is necessary to observe a sufficient height of the approach and outlet shafts so that the influence of the input of boundary conditions, the size and position of the cells and sufficient simulation time to stabilize the flow do not show. 
Qualitative agreement of the calculated water surface level profile by 2D and 3D models with RANS turbulence models $k-\omega, k-\varepsilon$ and LES model is relatively good, but quantitative agreement is insufficient. The water surface level calculated by numerical models in the section of the approach shaft and in the section of weir crest is significantly underestimated in the whole longitudinal plane of symmetry against to the measured. The relative error of the water surface level above the approach shaft is up to $10 \%$ and above the weir crest up to $18 \%$. The RANS models calculate the water surface level profile more accurately than the LES model. Simulation using a 3D model gives a qualitatively better information about the water surface level in the approach shaft than the 2D model. The calculated water surface profiles using the RANS turbulence models $k-\omega$ and $k-\varepsilon$ are very similar.

\section{ACKGNOWLEDGEMENT}

The article was created with the support of the project FAST-J-17-4577. Influence of the approach shaft geometry on the capacity of broad-crested weir and project FAST-S-18-5084 Flow with wakes in constructions.

\section{REFERENCES}

[1] Major J., 2020. Influence of inflow orientation on overflow characteristics over broad-crest (in Czech), Doctoral thesis, BUT, Brno.

[2] Major, J., Zachoval, Z. Numerical model of flow over broad-crested-weir with inlet shaft (in Czech).

Report of project ERASMUS+ č. 91/2017-2018, BUT, Brno, 2018.

[3] Major, J., Zachoval, Z. Influence of inflow shaft geometry on capacity of broad-crested weir (in

Czech). Report of project FAST-J-17-4577, BUT, Brno, 2018.

[4] Major, J. Influence of the transverse dimension of the inlet shaft on overflow of broad-crested weir (in Czech). Czech Journal of Civil Engineering. 2018.

[5] Afshar H., Hoseini S. H., 2013. Experimental and 3-D numerical simulation of flow over a rectangular broad-crested weir. International Journal of Engineering and Advanced Technology, 2(6), 214-219.

[6] Hargreaves D. M., Morvan H. P., Wright N. G., 2007. Validation of the volume of fluid method for free surface calculation: The broad-crested weir. Engineering Applications of Computational Fluid Mechanics, 1(2), 136-146.

[7] Kirkgoz M. S., Akoz M. S., Oner A. A., 2008. Experimental and theoretical analyses of twodimensional flows upstream of broad-crested weirs. Canadian Journal of Civil Engineering, 35(9), 975-986.

[8] Lu X., Zou Q., Reeve D., 2011. Numerical simulation of overflow at vertical weirs using a hybrid level set/VOF method. Advanced in Water Resources, 34(10), 1320-1334.

[9] Sarker, M. A., Rhodes D. G., 2004. Calculation of free-surface profile over a rectangular broadcrested weir. Flow Measurement and Instrumentation, 15(4), 215-219, 2004.

[10] FLOW 3D. User manual, Version 9.3. Flow Science, Inc., 2008.

[11] MENTER, F. R. Improved Two Equation k- $\omega$ Turbulence Models for Aerodynamic Flows. Ames Research Center, Moffett Field, California, 1992.

[12] URUBA, V. Turbulence. CTU in Prague, 2014. 